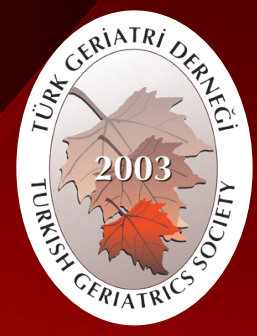

Turkish Journal of Geriatrics

DOI: $10.31086 /$ tigeri.2019150576

2019:22 (1):74-82

\section{- Mehmet Ali TALMAÇ ${ }^{1}$ (D) \\ - Mehmet Akif GÖRGEL ${ }^{1}$ D \\ - Muharrem KANAR ${ }^{1}$ D \\ - Şervin RAFiD \\ - Hacı Mustafa ÖZDEMIR ${ }^{1}$ (D)}

CORRESPONDANCE

Mehmet Ali TALMAÇ

Health Sciences University, Şişli Hamidiye Etfal

Education and Research Hospital, Department of

Orthopaedics and Traumatology Istanbul/Turkey

Phone: 02123735003

e-mail: drtalmac2@gmail.com

Received: $27 / 09 / 2018$

Accepted: 29/12/2018

Health Sciences University, Şişli Hamidiye Etfal Education and Research Hospital,

Department of Orthopaedics and

Traumatology ìstanbul/Turkey

\title{
CLINICAL AND LABORATORY FINDINGS OF SEPTIC ARTHRITIS OF THE KNEE IN GERIATRIC AGE GROUP
}

\section{Abstract}

Introduction: Septic arthritis of the knee is a serious disease usually caused by bacterial infection. Although this disease is not age-restricted, many cases involve elderly people and young children. The present study evaluated the clinical and laboratory findings of patients aged $\geq 65$ years who underwent surgery for diagnosed septic arthritis of the knee.

Materials and Method: We retrospectively reviewed all patients' preoperative demographic data and comorbidities, as well as preoperative and postoperative clinical and laboratory findings. All patients were followed postoperatively at the 3rd and 6th weeks and 6th month and until a mean final follow-up of 36.0 21.6 (12-95) months.

Results: This retrospective clinical study included 56 patients (34 men, 22 women) who underwent surgery during 2010-2017. The mean age and body mass index $\left(\mathrm{kg} / \mathrm{m}^{2}\right)$ were 77.3 and 27.6 , respectively. In 43 patients (76.8\%), at least one infectious agent could be isolated from joint debridement material. The most commonly isolated bacterium was Staphylococcus aureus (28 patients, 50\%). Between all follow-up time points, we observed statistically significant decreases in C-reactive protein levels and erythrocyte sedimentation rates (both $p<0.001)$, well as significant increases in SF-36 scores $(p<0.001)$. Furthermore, visual analog scale scores decreased significantly between all follow-up time points $(p<0.001)$ except between the 6th postoperative month and final follow-up $(p=0.021)$.

Conclusion: Geriatric septic arthritis should be operated early. During postoperative empirical antibiotherapy, kidney function tests should be performed regularly. Further research is required for optimal management of geriatric knee SA.

Keywords: Geriatrics; Knee; Arthritis, Infectious; Therapeutics

ARAŞTIRMA

\section{GERIATRI YAŞ GRUBUNDA DIZ SEPTIKK ARTRITININ KLINIK VE LABORATUVAR BULGULARI}

\section{$\ddot{O}_{z}$}

Giriş: Diz septik artrit, çoğunlukla bakteriyel enfeksiyonların neden olduğu önemli bir hastalıktır. Her yaşta teşhis edilmesine rağmen, diz septik artrit genellikle yaşılır ve küçük çocuklarda görülür. Gecikmiş tanı ve tedavi eklem tahribatına yol açabilir. Bu durum morbidite ve mortaliteyi ciddi olarak artıır. Bu çalışmanın amacı, diz septik artrit tanısı ile ameliyat edilen 65 yaş veya üstü hastaların klinik ve laboratuvar sonuçlarını sunmaktır.

Gereç ve Yöntem: Çalışmaya sadece 65 yaş veya üstü hastalar dahil edildi. Hastalar preoperatif demografik verileri, preoperatif komorbiditeleri, preoperatif ve postoperatif klinik ve laboratuvar sonuçları açısından retrospektif olarak gözden geçirildi. Ortalama postoperatif takip süresi (ay) 36.0 21.6 (12-95) idi.

Bulgular: Bu çalışma retrospektif klinik çalışma olarak tasarlanmıştır. 2010-2017 yılları arasında diz septik artrit tanısı ile opere edilen 56 hasta (34 erkek, 22 kadın) çalışmaya dahil edildi. Yaş ve beden kütle indeksi ortalamaları sırasıyla 77.3 ve 27.6 idi. Eklem debridman materyalinden en az bir ajanın $43(\%$ 76,8) hastada izole edildiğini bulduk. En sık izole edilen bakteri staphylococcus aureus ( 28 olgu, $\% 50$ ) idi. Tüm takip süreleri arasında c-reaktif protein ve eritrosit sedimentasyon hızında istatistiksel olarak anlamlı azalma, SF-36 skor ortalamalarında ise istatistiksel olarak anlamlı artış saptandı $(p<0.001)$. Postoperatif 6 . ay ile son takip arasındaki azalma hariç $(p=0.021)$ tüm visual analog skala skorları istatistiksel anlamlı olarak azaldı $(p<0.001)$.

Sonuç: Geriatrik septik artrit erken ameliyat edilmeli ve postoperatif ampirik antibiyoterapi sırasında düzenli olarak böbrek fonksiyon testleri yapılmalıdır. Geriatrik diz septik artritinin optimal yönetimi için daha fazla araştırma gereklidir.

Anahtar sözcükler: Diz; Geriatri; Septik artrit; Tedavi 


\section{INTRODUCTION}

Septic arthritis (SA), an important condition included the differential diagnosis of an inflamed joint, is most frequently caused by bacterial infection (1). SA appears to be increasing due to population aging and the increased use of invasive orthopedic procedures and immunosuppressive treatments $(2,3)$. Although SA is not age-restricted, it often develops in elderly people and young children (4), and known risk factors include diabetes mellitus; prior rheumatic disease (e.g., rheumatoid arthritis); a low socioeconomic status; and history of surgery, leg ulcers, and intraarticular injections (5).

Septic arthritis, which most commonly affects the knee in adults, is among the most urgent conditions encountered in orthopedic practice, as delayed diagnosis and treatment can lead to joint destruction and systemic complications. However, a diagnosis of SA can present challenges even for orthopedic surgeons $(6,7)$. This is because of primarily increased joint degeneration and impairment immunity $(8,9)$. Despite the seriousness of this condition, very few studies on the morbidity, mortality and outcomes associated with SA in adult patients have been published in the last 10 years. Therefore, this study aimed to present the clinical and laboratory findings of patients aged $\geq 65$ years who were diagnosed with SA of the knee and underwent surgical treatment.

\section{MATERIALS AND METHOD}

This retrospective clinical study was conducted at The Department of Orthopedics and Traumatology of the Şişli Hamidiye Etfal Education and Research Hospital and was approved by the hospital Ethics Committee.

We identified 124 patients aged $\geq 18$ years who met one of the SA diagnostic criteria proposed by Newman (9) underwent surgery for SA of the knee during 2010-2017. Our exclusion criteria were age $<65$ years, diabetes-related foot infections, SA of a prosthetic joint, initial debridement in another institution and then transfer to our hospital, cognitive impairment, paresthesia of lower limbs, and a followup period of less than 1 year. Additionally, 5 patients died during follow-up. At finally, 56 patients (34 male, 22 female) were included in the study. The patients were stratified into two groups: 25 underwent surgery within the first 48 hours of the onset of complaints and were designated the early operated patient group, whereas 31 underwent surgery more than 48 hours after the onset of complaints and were designated the late operated patient group.

38 and 18 patients underwent arthroscopic and arthrotomic debridements, respectively. All procedurs were performed under spinal or general anesthesia. Povidone-iodine or chlorhexidine was used for sterile preparation and draping before both procedures. All arthrotomies were made anteromedially with a medial parapatellar approach. An anterolateral and an anteromedial portal was created for all arthroscopy procedures. In 4 cases, a superolateral portal was also created. After all procedures, the joint debridement material was sampled and was sent for culture. The joint was irrigated with the normal saline solution during both procedures. When the fluid returning from the joint was clear, we terminated the irrigation. Hypertrophied synovia, infected tissue, fibrinous debris, or other purulent material was debrided as necessary, openly or with an arthroscopic powered shaver. The arthrotomy or arthroscopy was closed, over a drain within the joint. The portals or arthrotomies were dressed.

Data for this study were collected from patient files and the digital databank at our hospital. We retrospectively reviewed all patients' preoperative demographic data and comorbidities, as well as preoperative and postoperative clinical and laboratory results. Serum white blood cell (WBC), c-reactive protein (CRP) and erythrocyte sedimentation rates (ESR) can be used as followup parameters in SA as in all infections. Quality of life for diseases related to the joint is often SF-36; subjective pain level is evaluated with visual analog scale (VAS) score $(10,11)$. The knee Lysholm and Tegner measurements are subjective and evaluate performance and activity restrictions after surgery (12). The Kellgren-Lawrence classification commonly use as a radiologic classification of osteoarthritis (13). 
The mean WBC counts, CRP levels, ESR, VAS and SF36 scores were assessed postoperatively at 3 and 6 weeks and 6 months, as well as the last follow-up. VAS scores were determined on a scale of 0-10. The mean knee Lysholm and Tegner scores and mean KellgrenLawrence classification scores were also evaluated at 6 months and the last follow-up. The early operated and late operated patient groups were compared in terms of these latter three scores at 6 months postoperatively and at the last follow-up to evaluate the effects of early and late surgery on osteoarthritis progression.

SPSS 22.0 for Windows 7 (IBM, Inc., Armonk, NY, USA) was used for the statistical analysis. Categorical variables are reported as numbers and percentages, while numerical variables are reported as means, standard deviations and minimum-maximum ranges. A Friedman analysis was used to test inter-group differences in the numerical variables that were not normally distributed. Subgroup comparisons were made using a Wilcoxon analysis and interpreted using the Bonferroni correction. For normally distributed numerical variables, independent two-group comparisons were made using the Mann-Whitney $U$ test if Student's $t$ test did not provide a normal distribution. For all tests, statistical significance was defined as an alpha level of $p<0.05$.

\section{RESULTS}

Of the 61 patients, 5 (8.2\%) originally intended for inclusion in our analysis died; of them, four (80\%) died within the first 6 months of SA diagnosis. The mean age of the 56 surviving patients was $77.3 \pm 8.4$ (range: 65-93) years, the mean body mass index $\left(\mathrm{BMl} ; \mathrm{kg} / \mathrm{m}^{2}\right)$ was $27.6 \pm 4.1(19.8-40)$ and 34 patients $(60.7 \%)$ were male. The right side was affected in 32 patients (57.1\%). Etiologically, 45 patients (80.4\%) had hematogenous infections, 7 (12.5\%) had postoperative infections and four (7.1\%) had infections consequent to local injections. Additional preoperative demographic data and comorbidities are shown in Table 1. Further, 1, 4, 15, 20, and 16 patients had Charlson Comorbidity Index values of 4 , $3,2,1$ and 0 , respectively.
Preoperatively, the mean WBC count was $13967.5 \pm 3911.5 / \mathrm{mm}^{3}$ (6500-25200), the mean CRP level was $173.4 \pm 94.7 \mathrm{mg} / \mathrm{l}(57-452)$ and the mean preoperative ESR was $75.9 \pm 29.1 \mathrm{~mm} / \mathrm{h}$ (29-140). The mean interval between symptom onset and the surgical procedure was $4.7 \pm 4.6(1-25)$ days. Other preoperative laboratory and physical examination findings are shown in Table 2.

Postoperatively, patients were followed for a mean of 36.0 \pm 21.6 (12-95) months. Cultures were positive from the peroperative joint debridement material in 43 patients (76.8\%) and microbiological examination results are shown in Table 3. The mean length of hospital stay was $9.4 \pm 6.3$ (2-30) days. Cefazolin sodium or ampicillin sulbactam was administered as an intravenous empirical antibiotic and antibiotherapy was continued according to the antibiogram results. Intravenous antibiotherapy was administered for a mean of $10.1 \pm 6.3$ (3-30) days, while oral antibiotherapy (days) was administered for a mean of 24.6 \pm 5.9 (14-36) days. An empirical antibiotic change was required in 9 patients (16.1\%) due to a decrease in renal function. Further, 14 patients (25\%) experienced postoperative systemic and/or joint complications, and 8 patients (14.3\%) underwent reoperation because of a lack of improvement in clinical and laboratory parameters.

All postoperative decreases in WBC counts were statistically significant $(p<0.001)$ except between the 3 - and 6-week follow-up visits $(p=0.054)$. All decreases in CRP and ESR levels and all SF-36 score increases between the follow-up time points were statistically significant $(p<0.001)$. All decreases in VAS scores were statistically significant $(p<0.001)$ except for the decrease between the 6-month and last follow-ups $(p=0.021)$.

The mean knee Lysholm and Tegner scores exhibited statistically significant increases between the 6-month postoperative follow-up and last followup ( $p=0.001$ and $p=0.007$, respectively). Similarly, the increase in the mean Kellgren-Lawrence classification score between the 6- month and last follow-up was statistically significant $(p=0.008)$. Notably, the mean knee Lysholm and Tegner scores were significantly higher in the early operated group than in the late 
operated group at both the 6-month and at last follow-up time points (both $p<0.001)$. By contrast, the mean Kellgren-Lawrence classification scores were significantly lower in the early operated group, compared to the late operated group, at both the 6-month and last follow-up visits $(p=0.003$ and $\mathrm{p}=0.002$, respectively) (Table 4).

Table 1. Demographic properties of the patients.

\begin{tabular}{|c|c|}
\hline Variable & $\begin{array}{r}\text { All patients } \\
(n=56)\end{array}$ \\
\hline Age, years & $77.3 \pm 8.4(65-93)$ \\
\hline Male sex (n; \%) & $34(60.7)$ \\
\hline Right side (n; \%) & $32(57.2)$ \\
\hline BMI $\left(\mathrm{kg} / \mathrm{m}^{2}\right)$ & $27.6 \pm 4.1(19.8-40)$ \\
\hline Recent trauma $(n ; \%)$ & $1(1.8)$ \\
\hline Receiving systemic steroid therapy ( $\mathrm{n}$; \%) & $11(19.6)$ \\
\hline Previous joint disease ( $n ; \%)$ & $27(48.2)$ \\
\hline Previous knee surgery ( $n ; \%)$ & $10(17.9)$ \\
\hline Previous limb surgery ( $\mathrm{n} ; \%)$ & $3(5.3)$ \\
\hline \multicolumn{2}{|l|}{ Cause of infection } \\
\hline Hematogenous (n; \%) & $45(80.4)$ \\
\hline After surgery (n; \%) & $7(12.5)$ \\
\hline After a local injection ( $n$; \%) & $4(7.1)$ \\
\hline \multicolumn{2}{|l|}{ Comorbidities } \\
\hline $\mathrm{HT}(\mathrm{n} ; \%)$ & $21(37.5)$ \\
\hline $\mathrm{DM}(\mathrm{n} ; \%)$ & $12(21.4)$ \\
\hline $\operatorname{CAD}(n ; \%)$ & $2(3.6)$ \\
\hline $\mathrm{RA}(\mathrm{n} ; \%)$ & $5(8.9)$ \\
\hline $\operatorname{CKF}(n ; \%)$ & $9(16.1)$ \\
\hline Hypotiroidism (n; \%) & $1(1.8)$ \\
\hline $\operatorname{COPD}(n ; \%)$ & $1(1.8)$ \\
\hline Asthma (n; \%) & $4(7.1)$ \\
\hline Alzheimer's disease (n; \%) & $2(3.6)$ \\
\hline $\mathrm{GA}(\mathrm{n} ; \%)$ & $2(3.6)$ \\
\hline FMF (n; \%) & $1(1.8)$ \\
\hline Immunosuppression ( $n$; \%) & $12(21.4)$ \\
\hline
\end{tabular}

Values are expressed as means \pm standard deviations (mean \pm SD) and minimum-maximum ranges (min-max) or as numbers of patients (n) and percentages (\%).

BMI: Body mass index, HT: Hypertension, DM: Diabetes mellitus, CAD: Coronary artery disease, RA: Rheumatoid arthritis, CKF: Chronic kidney failure, COPD: Chronic obstructive pulmonary disease, GA: Gout arthritis, FMF: Familial Mediterranean fever 
Table 2. Preoperative physical examination findings and laboratory results.

\begin{tabular}{|c|c|}
\hline Variable & $\begin{array}{r}\text { All patients } \\
(n=56)\end{array}$ \\
\hline Preoperative VAS score & $7.2 \pm 1.0(6-9)$ \\
\hline Joint effusion (n; \%) & $46(82.1)$ \\
\hline Walking without support before admission ( $\mathrm{n} ; \%)$ & $23(41.1)$ \\
\hline Fever before admission ( $\mathrm{n} ; \%$ ) & $24(42.9)$ \\
\hline Days with symptoms before the surgical procedure & $4.7 \pm 4.6(1-25)$ \\
\hline WBC count $\left(/ \mathrm{mm}^{3}\right)$ & $13967.5 \pm 3911.5(6500-25200)$ \\
\hline CRP level (mg/l) & $173.4 \pm 94.7(57-452)$ \\
\hline $\operatorname{ESR}(\mathrm{mm} / \mathrm{h})$ & $75.9 \pm 29.1(29-140)$ \\
\hline \multicolumn{2}{|l|}{ Preoperative synovial fluid examination } \\
\hline White blood cells & $\begin{array}{r}111100.0 \pm 104260.4 \\
(13600-720000)\end{array}$ \\
\hline Glucose (mg/dL) & $45.9 \pm 17.3(15-78)$ \\
\hline Positive gram stain (n; \%) & $21(37.5)$ \\
\hline Positive synovial fluid culture (n; \%) & $21(37.5)$ \\
\hline Creatinine clearance (ml/min) & $79.5 \pm 40.2(13.6-246.6)$ \\
\hline
\end{tabular}

Values are expressed as means \pm standard deviations (mean $\pm \mathrm{sd}$ ) and minimum-maximum ranges (min-max) or as numbers of patients ( $\mathrm{n}$ ) and percentages (\%).

CRP: C-reactive protein, ESR: Erythrocyte sedimentation rate, VAS: Visual analog scale that evaluates the subjective pain on a scale of 0-10, WBC: White blood cell

Table 3. The peroperative joint debridement material microbiological examination results.

\begin{tabular}{lr}
\hline Variable & $\begin{array}{r}\text { All patients } \\
(\mathbf{n} ; \%)\end{array}$ \\
\hline Culture negative patients & $13(23.2)$ \\
Culture positive patients & $43(76.8)$ \\
Staphylococcus aureus & $28(50)$ \\
Staphylococcus epidermidis & $4(7.2)$ \\
Coagulase-negative Staphylococcus & $3(5.3)$ \\
Streptococcus A & $3(5.3)$ \\
Streptococcus G & $2(3.6)$ \\
Corynebacterium & $2(3.6)$ \\
Enterobacter cloacae & $1(1.8)$ \\
Total number & $56(100)$ \\
\hline
\end{tabular}

Values are expressed as as numbers of patients ( $n$ ) and percentages (\%). 
Table 4. Effect of early surgery on osteoarthritis.

\begin{tabular}{|c|c|c|c|}
\hline Variable & $\begin{array}{r}\text { Early operated } \\
\text { patients }(n=25) \\
\text { Mean } \pm s d\end{array}$ & $\begin{array}{r}\text { Late operated } \\
\text { patients }(n=31) \\
\text { Mean } \pm s d\end{array}$ & $\mathbf{p}$ \\
\hline 6-month follow-up Lysholm score & $58.6 \pm 5.4$ & $72.4 \pm 5.1$ & $<0.001$ \\
\hline 6-month follow-up Tegner score & $3.4 \pm 0.3$ & $4.3 \pm 0.2$ & $<0.001$ \\
\hline $\begin{array}{l}\text { 6-month follow-up Kellgren-Lawrence classification } \\
\text { score }\end{array}$ & $3.2 \pm 1.0$ & $2.4 \pm 0.8$ & 0.003 \\
\hline Last follow-up Lysholm score & $60.3 \pm 5.5$ & $73.9 \pm 6.1$ & $<0.001$ \\
\hline Last follow-up Tegner score & $3.5 \pm 0.4$ & $4.4 \pm 0.3$ & $<0.001$ \\
\hline Last follow-up Kellgren-Lawrence classification score & $3.3 \pm 0.9$ & $2.5 \pm 0.8$ & 0.002 \\
\hline
\end{tabular}

The values are expressed as means \pm standard deviations (mean \pm sd).

$P$ value $<0.05$ was considered to indicate statistical significance.

\section{DISCUSSION}

Advanced age is a risk factor for SA and a predictor of mortality (14). According to the literature, $40 \%-$ $60 \%$ of adult patients with SA are at least 65 years of age $(3,15)$. Similarly, $61(49.2 \%)$ of the 124 adult patients who met our study criteria were at least 65 years of age. Previous studies have reported high morbidity and mortality rates among patients with geriatric $\mathrm{SA}$, and in such cases, death usually occurs within the first 6 months $(14,16)$. Consistent with those findings, we observed a high risk of mortality in our study population, wherein five of the 61 originally identified patients (8.2\%) had died; of them, $80 \%$ had died within the first 6 months after the SA diagnosis. Additionally, several types of comorbidities have been observed in geriatric patients with $S A$, including osteoarthritis $(O A), H T$, DM, CAD, COPD, GA, stroke, CKF, hypothyroidism, asthma, liver disease, congestive heart failure, cancer, immunosuppression, and RA. In a previous mortality study, male sex, advanced age, COPD, DM, GA, congestive heart failure, stroke, kidney disease, liver disease, cancer and RA were identified as independent determinants of mortality (15). Consistent with those findings, our 56 patients had a mean age of $77.3 \pm 8.4(65-93)$ years and a slight male predominance (34 men, 60.7\%), and the most common comorbidities were HT $(n=21,37.5 \%)$, immunosuppression $(n=12,21.4 \%)$ and RA $(n=8$, $14.3 \%)$.

A differential diagnosis of acute monoarticular arthritis should include hemarthrosis, SA, crystalline arthritis, foreign body synovitis, avascular necrosis and Lyme disease. The most obvious physical findings of knee SA include redness, regional febrility, pain, a decreased joint range of motion and swelling. A diagnosis of SA should also be considered even in the absence of symptoms of systemic infection, as findings such as a systemic fever exceeding $39^{\circ} \mathrm{C}$ have been reported in only $30 \%-40 \%$ of patients with SA (17). Similarly, only 24 patients $(42.9 \%)$ in our study had a preoperative systemic high fever.

During diagnosis, preoperative VAS scores are generally not evaluated, despite that pain is one of the most important examination findings in a case of knee SA $(1,4,7,17)$. In our study, our patients had a preoperative mean VAS score of $7.2 \pm 1.0$ (6-9) and we wanted to contribute to the literature about preoperative knee pain in patients with geriatric knee SA. Furthermore, our observation of preoperative joint effusion in $82.1 \%$ of cases in our study was consistent with previously published rates 
of $60 \%-90 \%(14,17)$. We note that our value was close to the upper limit reported in the literature and suggest that knee $O A$, which affects the majority of geriatric patients, increases susceptibility to joint effusion.

Similarly, the ability to walk without assistance is also infrequently evaluated in studies of knee SA. In our study, 23 patients (41.1\%) were able to walk without support, suggesting that acute knee SA is also a serious problem in the geriatric population. Possibly, some patients who rely on ambulatory support may delay a visit to the hospital because the symptoms of knee SA are not obvious. Furthermore, many studies have not reported data on the interval between symptom onset and diagnosis, although one retrospective study reported an average of 11.4 days (18). By contrast, we observed a mean of $4.7 \pm 4.6(1-25)$ days with symptoms prior to surgery. Consistent with several studies of all-adult or only geriatric SA populations $(7,17)$; however, the average preoperative $\mathrm{WBC}, \mathrm{CRP}$ and ESR values were within normal limits in our study and our synovial examination findings were consistent with the literature (19).

In our study, at least one agent could be isolated from joint debridement material in 43 patients (76.8\%), consistent with a previous report wherein the causal agent could not be isolated in only $24.2 \%$ of the patients (20). In our study, Staphylococcus aureus was the most common causal agent. Furthermore, we observed that the majority of patients were infected by Gram-positive bacteria, consistent with the previous series (20). Our results suggest little difference between geriatric and nongeriatric adults in terms of the causal agents of knee SA. Similarly, the mean durations of intravenous and oral antibiotic administration were consistent with the literature. However, our study observed a longer mean length of hospital stay and higher empirical antibiotic change and reoperation rates, compared to previous reports $(17,20)$. A decrease in renal function necessitated an empirical antibiotic change in all nine affected patients (16.1\%) in our study, suggesting that renal function tests should be performed regularly in all geriatric patients receiving empirical antibiotic therapy for knee SA. Furthermore, the prolonged hospital stay increases the need to monitor patients for to hospital infections and other complications.

In accordance with the literature, we observed decreases in the mean peripheral blood WBC counts beginning at the 3-week follow-up, as well as decreases in the mean CRP and ESR values to normal levels by the 6-month follow-up $(3,15,21)$. The mean VAS score decreased significantly until the 6-month follow-up then plateaued, suggesting that the main clinical and laboratory improvements occurred in the first 6 months. Additionally, the lack of a statistically significant decrease after 6 months suggests a pre-existing knee pathology, such as $O A$. However, the continuous and significant increase in the mean SF-36 score throughout the followup period suggests that clinical healing does not correlated solely with the VAS score.

In our population, the statistically significant increases in the mean knee Lysholm, knee Tegner and Kellgren-Lawrence scores between 6 months and the last follow-up time point indicate continued clinical improvement beyond 6 months. However, OA progressed radiologically due to past SA. Notably, patients who underwent surgery within 48 hours of symptom onset had significantly higher mean Lysholm and Tegner scores and significantly lower mean Kellgren-Lawrence scores at the 6-month and last follow-ups when compared to other patients. These findings suggest that geriatric SA patients should undergo surgery as soon as possible, as this could accelerate a functional recovery and prevent the rapid development of OA.

Despite our informative findings, this study had some limitations, including a retrospective and noncomparative study design and relatively small number of patients. However, the most important strengths of this study included the single-center setting, narrow inclusion criteria (including an age 
limit of $\geq 65$ years) and detailed assessment of both preoperative and postoperative functional and laboratory results for all patients.

In conclusion, knee SA is associated with increased morbidity and mortality in the geriatric population, and the associated joint destruction may induce OA of the knee. Therefore, SA should not be excluded from the differential diagnosis of a geriatric patient with a swollen, inflamed knee. Accordingly, patients should be questioned carefully about preoperative comorbidities, and

\section{REFERENCES}

1. García-Arias M, Balsa A, Mola EM. Septic arthritis. Best Pract Res Clin Rheumatol 2011;25(3):407-21. (PMID:22100289).

2. Geirsson AJ, Statkevicius S, Víkingsson A. Septic arthritis in Iceland 1990-2002: increasing incidence due to iatrogenic infections. Ann Rheum Dis 2008;67(5):638-43. (PMID:17901088).

3. Mathews CJ, Weston VC, Jones A, Field M, Coakley G. Bacterial septic arthritis in adults. Lancet 2010;375(9717):846-55. (PMID:20206778).

4. Ferrand J, El Samad Y, Brunschweiler B, et al. Morbimortality in adult patients with septic arthritis: a three-year hospital-based study. BMC Infect Dis 2016;16(6):239-49. (PMID:27246346).

5. Mathews CJ, Coakley G. Septic arthritis: current diagnostic and therapeutic algorithm. Curr Opin Rheumatol 2008;20(4):457-62. (PMID:18525361).

6. Al-Nammari SS, Bobak P, Venkatesh R. Methicillin resistant Staphylococcus aureus versus methicillin sensitive Staphylococcus aureus adult haematogenous septic arthritis. Arch Orthop Trauma Surg 2007;127(7):537-42. (PMID:17260151).

7. Mathews CJ, Weston VC, Jones A, Field M, Coakley G. Bacterial septic arthritis in adults. Lancet 2010;375(9717):846-55. (PMID:20206778)

8. Clerc O, Prod'hom G, Greub G, Zanetti G, Senn L. Adult native septic arthritis: a review of 10 years of experience and lessons for empiricalantibiotic therapy. J Antimicrob Chemother 2011;66(5):116873. (PMID:21393124). a risk analysis should be performed. Geriatric patients with SA should quickly undergo surgery and postoperative short-, mid- and long-term clinical and laboratory follow-up results should be monitored carefully. Better clinical and laboratory results will require additional research such as joint drainage procedures, improved diagnosis methods, treatment duration, and antibiotic regimens into the optimal management of geriatric knee SA.

\section{Conflict of interests}

There are no conflicts of interest to declare.

9. Newman JH. Review of septic arthritis throughout the antibiotic era. Ann Rheum Dis 1976;35(3):198205. (PMID:984899).

10. Ware JE. Measuring patients' views: the optimum outcome measure. BMJ 1993;306(6890):1429-30. (PMID:8518638)

11. Flaherty SA. Pain measurement tools for clinical practice and research. AANA J 1996;64(2):133-40. (PMID:9095685)

12. Tegner $Y$, Lysholm J. Rating systems in the evaluation of knee ligament injuries. Clin Orthop Relat Res 1985;198(9):43-9. (PMID:4028566).

13. Kellgren JH, Lawrence JS. Osteo-arthrosis and disk degeneration in an urban population. Ann Rheum Dis 1958;17(4): 388-97. (PMID:13606727).

14. Kennedy N, Chambers ST, Nolan I, et al. Native joint septic arthritis: Epidemiology, clinical features, and microbiological causes in a New Zealand population. J Rheumatol 2015;42(12):2392-7. (PMID:26523022).

15. Wu CJ, Huang CC, Weng SF, et al. Septic arthritis significantly increased the long-term mortality in geriatric patients. BMC Geriatr 2017;17(1):178. (PMID:28793879).

16. Gavet F, Tournadre A, Soubrier M, Ristori JM, Dubost JJ. Septic arthritis in patients aged 80 and older: a comparison with younger adults. J Am Geriatr Soc 2005;53(7):1210-3. (PMID:16108940).

17. Nair R, Schweizer ML, Singh N. Septic arthritis and prosthetic joint infections in older adults. Infect Dis Clin North Am 2017;31(4):715-29. (PMID:29079156). 
18. Helito CP, Zanon BB, Miyahara Hde S" et al. Clinical and epidemiological differences between septic arthritis of the knee and hip caused by oxacillinsensitive and -resistant s. aureus. Clinics (Sao Paulo) 2015;70(1):30-3. (PMID:25672426).

19. Lin WT, Tang HJ, Lai CC, Chao CM. Clinical manifestations and bacteriological features of culture-proven Gram-negative bacterialarthritis. J Microbiol Immunol Infect 2017;50(4):527-531. (PMID:26455489).
20. Dubost JJ, Soubrier M, Sauvezie B. Pyogenic arthritis in adults. Joint Bone Spine 2000;67(1):11-21. (PMID:10773964).

21. Smith JW, Chalupa P, Shabaz Hasan M. Infectious arthritis: clinical features, laboratory findings and treatment. Clin Microbiol Infect 2006;12(4):309-14. (PMID:16524406). 